\title{
Fusarium Crown Rot of Winter Wheat Influenced by Resource Competition Near a Tree Windbreak
}

\author{
Richard W. Smiley ${ }^{\dagger}$ and Stephen Machado \\ Oregon State University, Columbia Basin Agricultural Research Center, P.O. Box 370, Pendleton, OR 97801
}

\begin{abstract}
Fusarium crown rot becomes most severe when wheat is stressed for water near the time of anthesis. This research examined the potential to study crown rot in the gradient of resource competition near a tree windbreak. Winter wheat was planted for 2 years into a field infested by Fusarium pseudograminearum and bordered by 17-m-high Austrian pines. Crown rot, plant growth and yield, and soil water content were evaluated at six distances ( 5 to $46 \mathrm{~m}$ ) perpendicular to the tree line in strip plots in-

tree height; $0.5-1.8 \mathrm{H})$. At $46 \mathrm{~m}(2.7 \mathrm{H})$, crown rot was similar in noninoculated and inoculated strips ( 2 to $5 \%$ whiteheads). Whiteheads and culm browning were roughly the reverse of soil water depletion by tree roots. Grain yield at $23 \mathrm{~m}$ compared with $46 \mathrm{~m}$ was reduced by 33 to $35 \%$ in noninoculated plots and by 43 to $49 \%$ in inoculated plots. It is possible to study associations between water stress and Fusarium crown rot in the zone of resource competition near windbreaks.
\end{abstract} oculated or not inoculated with the pathogen. Crown rot was minor $(<5 \%$ whiteheads) in noninoculated strips and greater in inoculated strips (26 to $35 \%$ ) in a $21-\mathrm{m}$ zone from 9 to $30 \mathrm{~m}$ from the tree line $(0.5-1.8$ times the
Keywords: Fusarium pseudograminearum, wheat, Fusarium crown rot, water stress gradient
Production and quality of winter wheat (Triticum aestivum L.) in the semiarid region of eastern Oregon and Washington are dependent upon the availability of water deep within the soil profile at the time when grain kernels are filling and maturing (Schillinger et al. 2006). Most precipitation in the region occurs from autumn through spring, when winter wheat plants are in the seedling and tillering growth stages. Soaking rain during the summer is rare and, when it occurs, it generally does not rewet soil into the root zone. Fusarium crown rot is a chronic disease of winter wheat in the region and is greatly exacerbated when plants are subjected to late-season drought stress (Cook 1968, 1980, 1981; Poole et al. 2013; Smiley and Patterson 1996; Smiley et al. 2005a).

Fusarium crown rot (crown rot) is caused by Fusarium pseudograminearum (O'Donnell \& Aoki) (=Gibberella coronicola) and $F$. culmorum (Wm. G. Sm.) Sacc., either alone or in mixed populations (Poole et al. 2013; Smiley and Patterson 1996). These soilborne pathogens invade crown and basal stem tissues and ultimately reduce transmission of water from the roots to the foliar canopy. When basal tissues of individual tillers become heavily invaded by a crown rot pathogen, the disease process culminates with a premature senescence of heads, called whiteheads (Burgess et al. 2001; Cook 1981, 1990; Hollaway and Exell 2010; Klein et al. 1991; Liu and Liu 2016; Papendick and Cook 1974; Poole et al. 2013).

Crown rot severity rapidly progresses from a chronic, lowimpact disease to an acute, highly damaging disease during years in which drought stress occurs during or after anthesis (Burgess et al. 2001; Cook and Papendick 1970; Smiley 2009; Smiley et al. 2009); Zadoks growth stages 60 to 90 (Zadoks et al. 1974). During a drier-than-average year in eastern Oregon, Smiley et al. (2005b) evaluated 13 commercial fields of soft-white winter wheat

${ }^{\dagger}$ Corresponding author: R. Smiley; richard.smiley@ oregonstate.edu

Funding: Research was funded by the Oregon Agricultural Experiment Station and a grant from the USDA-Agricultural Research Service Cereal Root Disease Research Unit.

The author(s) declare no conflict of interest.

Accepted for publication 4 September 2019.

(C) 2020 The American Phytopathological Society for crown rot incidence and severity relative to yield components. Plants that exhibited symptoms of crown rot in the 13 fields ranged from 24 to $98 \%$, with a mean of $76 \%$. Reduction of grain yield ranged from zero to $35 \%$ (mean of $10 \%$ ), grain protein content became elevated as much as $17 \%$, and grain kernel weight became reduced as much as $23 \%$. Soft-white winter wheat is the major class of wheat produced in the region and is intended for export markets to produce lowprotein products such as cookies, crackers, noodles, and sponge cakes (Yamazaki and Greenwood 1981). Importers of soft wheat apply price discounts for protein contents higher than $9.5 \%$ and reduced test weights (Finney et al. 1987).

It is difficult to evaluate effects of soil moisture on the severity of crown rot. Experiments to examine crown rot under variable watering of maturing wheat in greenhouse pots are seldom successful because whiteheads rarely occur in pot studies. Greenhouse pots confine roots of mature plants into small volumes of soil, where the rapid onset of water deficits are difficult to control without frequent watering to prevent terminal wilting. While crown rot symptoms identical to those found on mature plants in the field have been reproduced in the greenhouse, such studies require careful regulation of water in tall rubbish bins filled with soil (Liddell et al. 1986). Most water-related studies of crown rot are therefore conducted in field experiments, where unpredictable precipitation may lead to the failure of experiments during years when few or no whiteheads appear. If an adequate supply of moisture is available to the plant during the late growth stages, whiteheads will rarely become expressed even though the severity of crown rot and yield reduction may be substantial (Burgess et al. 2001).

Reliable water-related experiments with crown rot in the field therefore require a suitable irrigation system or a mobile rainexclusion shelter, depending on the precipitation characteristics of each region. In semiarid regions where effective summer rainfall is lacking during wheat maturation, experiments may involve delivery of supplemental water to eliminate postanthesis water stress on a portion of the experimental area. One model is a line-source irrigation study in which experimental variables are replicated perpendicular to an irrigation line for the purpose of monitoring plant growth, disease, or other factors under progressively lower levels of available water. An alternate option in regions where summer rainfall is more plentiful is to use track-mounted rain-exclusion shelters that can be moved into place to prevent wetting during certain precipitation events and to therefore induce water-stress variables in selected 
portions of the experimental area (Davies 2014). Both options require expensive facilities, access to a source of water and/or electricity, and/or watering at times when wind does not interfere with distribution of water.

Another option that does not appear to have been evaluated is the placement of Fusarium crown rot studies into fields where natural gradients of water stress occur without the need to supply additional water or to exclude excess water. Rows of trees are planted as windbreaks (shelterbelts) along driveways, fence lines, and around rural farmsteads in many regions (Alemu 2016; Ross 1972). Lines of narrowly spaced trees slow the velocity of wind, reduce blowing dust, reduce heat loss around buildings, protect livestock, provide wildlife habitat, reduce sound transmission from roads to nearby buildings, and trap wind-blown snow (Alemu 2016; Bird et al. 1992; Read 1964). Farmers in the United States are eligible for financial assistance to establish and renovate windbreaks (NRCS 2009). Austrian pine (Pinus nigra Arnold) is a shelterbelt species that has been of particular importance because it is long-lived, widely adapted, and produces a dense canopy without an abundance of surface roots (Read 1964).

While windbreak trees contribute many positive attributes to the leeward direction of prevailing winds (Bennell and Verbyla 2008), they also compete for resources such as water, light, and nutrients within the root zone on both sides of the tree line. The zone of resource competition depends on many factors that include the rooting habit of the tree species, tree size, crop species, soil texture, soil depth, and amount and seasonal distribution of precipitation. In general, the zone of resource competition on the windward direction can extend into nearby crops as far as three times the height of the tree (Bates 1911; Kort 1988; Sudmeyer and Scott 2002; Sudmeyer et al. 2002a, 2002b). Windbreaks in semiarid and arid regions reduce growth and yield of adjacent crops mostly through competition for water (Bird et al. 1992; Brenner 1991; Greb and Black 1961; Nuberg 1998). In particular, Sudmeyer et al. (2002b) evaluated factors of the competition and found that reduced yields of crops adjacent to Pinus pinaster Aiton and Eucalyptus globulus Labill windbreaks in southwest Australia were caused primarily by water stress rather than by competition for nutrients or light.

Unpublished annual reports from the Columbia Basin Agricultural Research Center revealed that two wheat breeders reported losses of one or more replicates of data due to experiments being planted too close to the windward (west) side of Austrian pine windbreaks. Dr. J. F. Martin reported that wheat growth in 1938 was affected to a distance of $18 \mathrm{~m}$ from an 8 -year-old windbreak. Dr. O. A. Vogel reported that wheat growth in 1950 was diminished to a distance of $30 \mathrm{~m}$ when that same windbreak was 20 years old. In each case, the competition was detected from grain yield data rather than from real-time observations. A similar occurrence was detected in 2003, when winter wheat growth appeared to have been affected by competition in a wide band extending in the windward (west) direction from a 36-yearold shelterbelt consisting of a single row of Austrian pines. Drainage of water below the root-zone in the deep silt loam at that location is negligible (Chen et al. 2003), indicating that depletion of water was due to competitive uptake by roots of trees and wheat, plus additional depletion by surface evaporation. Under such conditions, tree roots are typically confined to the upper $1.2 \mathrm{~m}$ of the soil profile (Yeager 1935), and the vertical zone of competition is in the upper 0.3 to $0.5 \mathrm{~m}$ of the soil profile (Sprackling and Read 1979). Many studies have shown that pruning of tree roots has increased crop yields on the windward side of shelterbelts (Lyles et al. 1984; Nuberg 1998; Rasmussen and Shapiro 1990).

The objective of this research was to evaluate the possibility of studying water stress gradient effects on Fusarium crown rot under uncontrolled but predictable competition for water by tree roots growing under wheat crops. We report results of two successive winter wheat crops in a field adjacent to an Austrian pine windbreak at the Columbia Basin Agricultural Research Center.

\section{Materials and Methods}

The Columbia Basin Agricultural Research Center (CBARC; $45.7120 ;-118.6278$ ) is $13 \mathrm{~km} \mathrm{NE}$ of Pendleton, at an altitude of $460 \mathrm{~m}$. The climate is temperate with warm, dry summers $\left(21^{\circ} \mathrm{C}\right)$ and cool, wet winters $\left(1^{\circ} \mathrm{C}\right)$. About $75 \%$ of the $455 \mathrm{~mm}$ mean annual precipitation occurs from November to May (Smiley et al. 1996). Pan evaporation exceeds precipitation from March through October. The soil is a deep, well-drained Walla Walla silt loam (coarse-silty mesic Typic Haploxeroll). The standard cropping sequence in the region consists of a crop of winter wheat (10-month growing season) rotated with a 14-month period of cultivated or noncultivated summer fallow (Schillinger et al. 2006). We report two experiments on successive winter wheat crops that were harvested during 2005 and 2007.

An aerial photograph was taken during a period of hot and dry weather when winter wheat was in the anthesis stage on 12 June 2003 (Fig. 1). The image showed a visible, sharply delimited zone of competition between the wheat and trees that extended westward into the wheat crop as far as 27 to $37 \mathrm{~m}$ from the trunks of the 36 year-old Austrian pine windbreak. The competitive interaction was not detected by visual observation at ground level. Measurements of tree heights and lengths of the longest limbs revealed heights from 15.9 to $19.2 \mathrm{~m}$ (mean $17.1 \mathrm{~m}$ ), and the longest branch extended $7 \mathrm{~m}$ from the tree trunks toward the wheat crop. Competition for resources therefore extended into the crop for a distance up to 2.1 times the average measured height of the trees $(2.1 \mathrm{H}$, where $\mathrm{H}$ is the height of the trees), and about $30 \mathrm{~m}$ beyond the tips of the longest branches. Grain yield and test weight were determined in August 2003 by harvesting parallel $12-\mathrm{m}$-wide strips of wheat at successive distances from the tree line. Grain yield was lower in strips harvested within $24 \mathrm{~m}$ of the tree line $(<3,800 \mathrm{~kg} / \mathrm{ha})$ versus strips harvested outside that zone $(>5,000 \mathrm{~kg} / \mathrm{ha})$. Grain test weights were also lower within $24-\mathrm{m}$ of the tree line $\left(<680 \mathrm{~kg} / \mathrm{m}^{3}\right)$ versus outside that zone $(>720$ $\left.\mathrm{kg} / \mathrm{m}^{3}\right)$. These collective observations enabled us to select an experimental area spanning the range from 5 to $46 \mathrm{~m}$ from the tree line for this stress-related study of Fusarium crown rot during the 2005 and 2007 crop years.

After harvesting the 2003 winter wheat crop in August, the field was fallowed until October 2004. Standing stubble was retained on the surface through the 2003-2004 winter. Cultivated fallow was prepared during early spring (March 2004) using a chisel plow (Schillinger et al. 2006). At that time, an experimental area in the fallowed field was demarked for use during the next two crop years (Fig. 2). Four replicates of two future inoculum treatments (inoculated or not inoculated) were flagged in a direction perpendicular (east/west) to the north/south-oriented windbreak. The centerlines between pairs of inoculum treatments were at 20-m intervals. Twenty-four tubes (25.4-mm diam. $\times 2-\mathrm{m}$ depth) were installed into

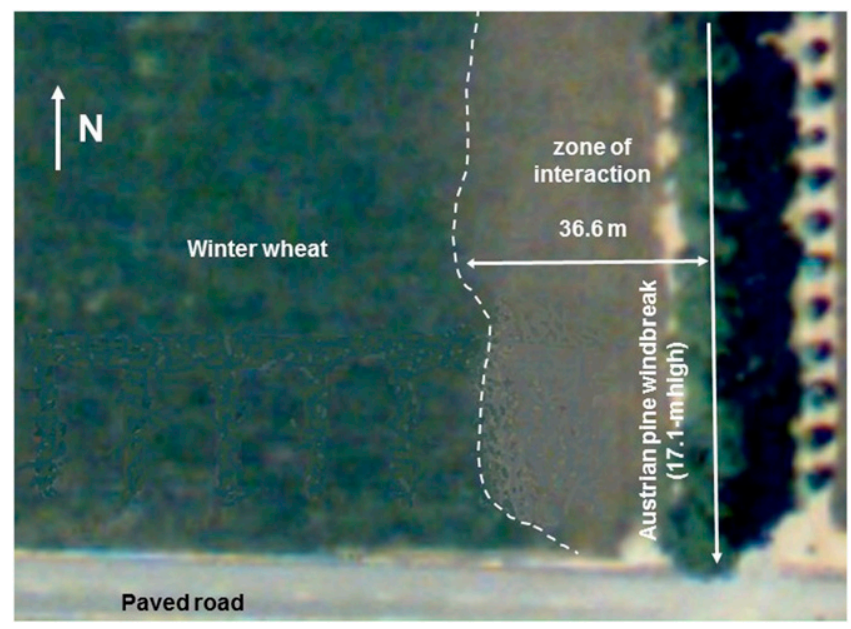

Fig. 1. Aerial image of a winter wheat field adjacent to a windbreak of Austrian pine trees near Pendleton, OR on 12 June 2003, showing the visible zone of competitive interaction between roots of wheat and trees. 
soil for use in measuring soil moisture in each centerline. Tubes were placed at $5,9,15,23,30$, and $46 \mathrm{~m}$ from the trunk-line within each centerline. The fallow was then completed using a rod weeder operated between the rows of tubes.

Soil water (percent by volume) in the fallow, without competition of a wheat crop, was measured at approximately 14-day intervals from 30 March to 22 June 2004. Measurements were made using a PR2 probe and recorded by a HH2 Data Logger (Delta-T Devices, Cambridge, UK). Data were recorded at depths of 15, 46, 76, and $107 \mathrm{~cm}$. Data consisted of three replicate counts at each depth level, so that each datum mean represented 12 measurements; 3 counts per depth in each tube $\times 4$ replicate tubes per distance from the tree line.

Shading of the experimental area was measured on 2 July 2004 at two locations west of the tree line. The distance to which shade extended into the experimental area from the tree line was measured at 30-min intervals from 0600 to $1200 \mathrm{~h}$. During August 2004, fertilizer was applied uniformly across the field at a rate based upon results of preplant soil tests. Fertilizer was applied with a shank applicator operated in a north-south direction, parallel to the tree line.

Soil in the field was naturally infested with a native population of F. pseudograminearum (Smiley and Patterson 1996) that was not quantified because this species survives as mycelium in pieces of crop refuse and is not easily quantified (Burgess et al. 2001; Cook 1981). Periodic samplings of soil and stubble did not reveal a presence of Fusarium culmorum in the field (Smiley and Patterson 1996; and R. Smiley, unpublished). Since crown rot pathogens are rarely distributed uniformly across fields, supplemental inoculum of the pathogen was prepared to compare wheat growth with and without supplemental inoculum. Isolates collected from infested winter wheat crowns during 1993 and 1994 (Smiley and Patterson 1996) were identified using morphological and molecular features (Nelson et al. 1983; Schilling et al. 1996; Williams et al. 2002). The isolates exhibited a wide range of aggressiveness ratings on wheat seedlings in a preliminary greenhouse assay (unpublished data), and were stored on silica beads at $4^{\circ} \mathrm{C}$ and on autoclaved barley seed at $-80^{\circ} \mathrm{C}$.

Inoculum was prepared by growing five isolates of $F$. pseudograminearum (93-82-03, 94-006-13, 94-32-06, 94-44-09, and 94-81-11) separately on 0.2 -strength potato dextrose agar medium and increasing each isolate individually in flasks containing twice-autoclaved millet seeds. After thorough colonization, the millet was air-dried, sieved to eliminate clumps, and stored at room temperature $\left(24^{\circ} \mathrm{C}\right)$ in paper bags. For use in field experiments, the millet colonized by individual isolates was blended in equal proportions to form a composite.

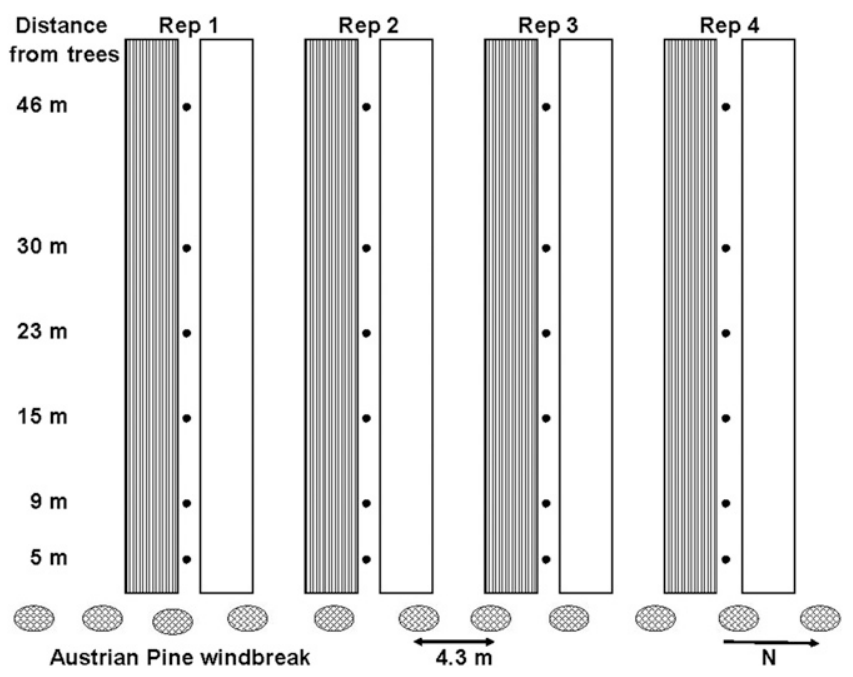

Fig. 2. Diagram of the Fusarium crown rot experiment in a winter wheat field adjacent to an Austrian pine windbreak, showing replicates of soil treated with $F$. pseudograminearum (striped columns) or not treated (open columns), locations of tubes for measuring soil moisture $(\bullet)$ between pairs of inoculum treatments, sampling distances from the base of the trees, and orientation of experiment.
On 4 Oct 2004, inoculum was delivered into field plots using a cone-seeder on a small-plot drill with $15-\mathrm{cm}$ row spacing. The millet seeds were deposited at the rate of $2.3 \mathrm{~g} / \mathrm{m}$ of row ( $\approx 200$ seeds $/ \mathrm{g}$ ) and were placed at 2-cm depth into a 3-m-wide strip on the south side of each row of soil moisture tubes. The drill was also used to make "control' passes in a 3-m-wide strip on the north side of the tubes, without depositing inoculum. Soil water was measured in each of the 24 tubes on 4 Oct, in the manner described previously.

The field was planted uniformly to winter wheat cv. 'Tubbs' on 5 Oct 2004, in a north-south orientation to a distance extending $60 \mathrm{~m}$ in the westward (windward) direction from the tree line. Wheat seeds were treated with benomyl (Benlate; DuPont Crop Protection, Wilmington, DE; $0.225 \mathrm{~g}$ a.i./kg of seed) to reduce or eliminate seedling damping-off associated with $F$. pseudograminearum (Wildermuth and McNamara 1994). Seed was planted into moist soil at a rate of 247 seeds $/ \mathrm{m}^{2}$ and a depth of $4 \mathrm{~cm}$.

Plant growth and disease were assessed in inoculated and control plots near each of the moisture tubes. Data in the 48 plots (6 distances from the tree line $\times 2$ inoculum treatments $\times 4$ replicates) included seedling emergence counts in 1-m row segments during mid-October, seedling height, and Haun growth stage (Haun 1973) for 20 plants/plot in November, and incidence of lesions on subcrown internodes and incidence of a brown rotting of the crown tissue for 20 plants/plot in February 2005. Soil water was measured at depths of $10,20,30,40,60$, and $100 \mathrm{~cm}$ during midApril and mid-May. Whitehead density (whiteheads $/ \mathrm{m}^{2}$ ) was determined on five dates over an 8-day period in late June and early July. Grain was harvested in early August from $1.5 \times 6 \mathrm{~m}$ segments of inoculated and noninoculated treatments centered on each of the six distances from the tree line. Grain was harvested with a small-plot combine, and grain yields and kernel weights were determined using standard procedures.

After harvest, at least 125 stems were collected and bagged from the standing stubble in each of four sampling sites near each of the 48 moisture tubes. Two sites were from inoculated strips and two sites were from noninoculated strips. Samples were taken within a 2-m distance diagonally northeast, southeast, northwest, and southwest of each tube. The replicates were collated and mixed before randomly selecting 100 stems to evaluate from each bag. The percentage of stems with at least one internode exhibiting the typical browning caused by crown rot was scored visually. Ten randomly selected culm bases from inoculated and noninoculated treatments were divided into $1-\mathrm{cm}$-long segments, split longitudinally, and halves of each segment were plated both onto 0.2-strength potato dextrose agar medium and wheat-leaf agar medium to identify the species associated with the crown rot symptom (Nelson et al. 1983).

Stubble from the 2005 wheat crop was retained on the experimental field during the winter. Soil was cultivated as previously described during the spring of 2006. Three additional measurements of soil water were made in the fallow at 3-week intervals during March and April of 2006.

The experiment was repeated during the 2007 crop year. During early September 2006, inoculum was applied as described earlier, winter wheat seed was treated with difenoconazole plus mefenoxam (Dividend Extreme; Syngenta Crop Protection, Greensboro, NC; $0.12+0.06 \mathrm{~g}$ a.i. $/ \mathrm{kg}$ of seed), and Tubbs winter wheat was planted. Seedling stand density was determined in late September. Soil moisture was measured once on $15 \mathrm{Feb}$. Whitehead density was assessed on three dates. Crown rot assessments and grain yield measurements were as described for the 2005 crop year.

Prior to analysis, percentage data for whiteheads and brown culms were normalized using the arcsine transformation (arcsine $\sqrt{ }[\% /$ 100]), and grain yield and test weight were normalized using the square-root transformation. Data were analyzed by univariate analysis of variance (ANOVA) using a strip-split plot design, with the inoculum treatment as the strip factor, distance from trees as the main plot factor, and year as the subplot factor. ANOVA was performed using Co-Stat Statistical Software (Co-Stat v. 6.400; CoHort Software, Monterey, CA). When treatment means were significant at $P<0.05$, data were reanalyzed using nontransformed data for 
comparative purposes. Data reported in this paper are from nontransformed data because there were no important differences detected for either statistical significance or separation of means. The factors of year and inoculum were each significant for most measures of plant growth and disease. Data for individual years were, therefore, also analyzed as a strip plot with inoculum as the main plot factor and distance as the subplot factor. Again, the inoculum factor was frequently significant, requiring further analysis of inoculum treatments separately for each year. This was performed by using a 1-way randomized block analysis to separate means across distances from the tree line within inoculum treatments. Treatment means significant at $P<$ 0.05 were separated using Fisher's least significant difference test (LSD). Linear and quadratic regression analyses were used to evaluate associations among selected experimental variables.

\section{Results}

Shade and precipitation. Solar noon at the experimental location varies from 1138 to $1144 \mathrm{~h}$ during the autumn months of October through December, and from 1152 to $1207 \mathrm{~h}$ during the spring and early summer months of March through June (https://www.esrl. noaa.gov/gmd/grad/solcalc). The sun's azimuth during these periods is 166 to 170 degrees, and 153 to 160 degrees, respectively. Sun elevation during these respective intervals is 22 to 40 degrees and 35 to 65 degrees. The peak elevation of the sun is therefore always located within 30 degrees of directly south of the tree line at solar noon. The image shown as Figure 1 was taken at 1426 h on 12 June 2003 and shows no shading of wheat adjacent to the tree line.

Shading of the experimental area was measured at 0600, 0700, $0800,0900,1000,1100$, and $1200 \mathrm{~h}$ on 2 July 2004 , which coincided with the time of maximum potential shading during the winter wheat crop year; sun azimuth and elevation were 149 and 65 degrees, respectively, at $1158 \mathrm{~h}$. Shading extended westward from the trunks of the Austrian pines for distances of 108, 61, 37, 22, 15, 11, and $9 \mathrm{~m}$, respectively. During crop years (2005 and 2007), wheat plants at the 15-, 9-, and 5-m distances were always fully exposed to sunlight after 1000, 1200, and $1300 \mathrm{~h}$, respectively.

Total precipitation during the 2004 fallow year $(509 \mathrm{~mm}$, from Sep 2003 to Aug 2004) was $19 \%$ higher than the long-term mean for the location. Rainfall prior to and immediately after planting the 2005 winter wheat crop (56 mm during Aug-Oct) was adequate for good seedling establishment. However, overall precipitation during the 2005 crop year $(309 \mathrm{~mm}$ ) was $27 \%$ lower than the 20 -year mean, with deficiencies occurring during autumn (Sep-Nov), winter (DecFeb), and grain filling (June-July). Precipitation during the 2006 fallow year $(479 \mathrm{~mm})$ was $12 \%$ higher than the long-term mean, but rainfall was particularly lacking during the 2 months before and immediately after the 2007 winter wheat crop was planted $(19 \mathrm{~mm}$ during Aug and Sep). Total precipitation during the 2007 crop year (389 mm) was $9 \%$ lower than the 20 -year mean, with deficiencies occurring during winter (12\%, Dec-Feb) and spring (27\%, Mar-May).

Wheat growth and development. Seedling stand density 2 weeks after seeding was significantly influenced by year $(P=0.0002)$ but not by distance from the tree line $(P=0.2561)$ or addition of inoculum of $F$. pseudograminearum $(P=0.8884)$. The interaction of year $\times$ distance was significant at $P<0.0001$, indicating a much lower plant density at the 5-m distance during 2007 than during 2005. Overall stand density was greater during 2005 than 2007 (29.1 versus 24.4 plants/m of row, $\mathrm{LSD}_{0.05}=2.8$ ) as shown in Table 1 .

Seedling height at 6 to 7 weeks after planting was significantly affected by year $(P<0.0001)$, distance $(P<0.0001)$, inoculation $(P=$ $0.0100)$, year $\times$ distance interaction $(P<0.0001)$, and year $\times$ inoculation interaction $(P=0.0030)$. The significant interactions revealed that plant heights were higher during 2007 than 2005 (27.4 versus $10.8 ; \mathrm{LSD}_{0.05}=1.3$ ), reflecting the earlier planting date in 2007. This was particularly apparent at distances nearest the tree line in noninoculated plots. Mean plant height was greater in the control than the inoculated treatment $\left(20.1\right.$ versus 18.0 ; $\left.\operatorname{LSD}_{0.05}=1.1\right)$. Mean plant height increased nearly uniformly from 5 to $46 \mathrm{~m}$ from the tree line (Table 1). Plant heights at the 5 and $9 \mathrm{~m}$ distances $(10.4$ to $17.0 \mathrm{~cm}$ ) were significantly less $\left(\mathrm{LSD}_{0.05}=2.5\right)$ than heights at the $46-\mathrm{m}$ distance $(23.6 \mathrm{~cm})$. This relationship was significant during each year of the test and in each inoculum treatment (Table 1).

Plant growth stage, in Haun units, at 6 to 7 weeks after planting was significantly affected by year $(P<0.0001)$ and distance $(P<$ $0.0001)$ but not by inoculation $(P=0.1947)$. None of the interactions among these treatments were significant. Growth stages were more advanced during 2007 than 2005 (2.30 versus 2.06 ; $\mathrm{LSD}_{0.05}=$ 0.03 ). Seedlings therefore had means of 2.3 fully extended leaves at sampling time during 2007 and 2.1 fully extended leaves during 2005, again reflecting an earlier planting during 2007 than 2005. Growth stage increased nearly uniformly from the $5 \mathrm{~m}$ to the $50 \mathrm{~m}$ distance from the tree line, and growth stages at the 5, 9, and $15 \mathrm{~m}$ distances (1.7 to 2.1$)$ were significantly less $\left(\mathrm{LSD}_{0.05}=0.2\right)$ than growth stages at the 23,30 , and $50 \mathrm{~m}$ distances (2.4 to 2.6). However,

Table 1. Winter wheat growth and yield as influenced by distance from an Austrian pine tree windbreak and presence or absence of supplemental inoculum of Fusarium pseudograminearum during two crop years. Stand density was measured 2 weeks after planting and plant height and growth stage were measured 6 to 7 weeks after planting, before winter dormancy.

\begin{tabular}{|c|c|c|c|c|c|c|c|c|c|}
\hline \multirow[b]{2}{*}{ Trait } & \multirow{2}{*}{$\begin{array}{l}\text { Inoculum } \\
\text { treatment }\end{array}$} & \multicolumn{7}{|c|}{ Distance from tree line (m) } & \multirow{2}{*}{$\begin{array}{c}\text { Inoculum } \\
\text { LSD } 0.05 \\
\end{array}$} \\
\hline & & 5 & 9 & 15 & 23 & 30 & 46 & LSD $_{0.05}$ & \\
\hline \multicolumn{10}{|l|}{2005 crop year } \\
\hline \multirow[t]{2}{*}{ Stand density (seedlings/m) } & Control & $26.3 \mathrm{a}^{\mathrm{y}}$ & $29.3 \mathrm{a}$ & $30.9 \mathrm{a}$ & $29.0 \mathrm{a}$ & $24.6 \mathrm{a}$ & $28.2 \mathrm{a}$ & ns & ns \\
\hline & Inoculated & $22.6 \mathrm{a}$ & $27.1 \mathrm{a}$ & $31.4 \mathrm{a}$ & $28.7 \mathrm{a}$ & $22.7 \mathrm{a}$ & $30.1 \mathrm{a}$ & ns & \\
\hline \multirow[t]{2}{*}{ Plant height $(\mathrm{cm})$} & Control & $6.2 \mathrm{~d}$ & $10.8 \mathrm{c}$ & $11.7 \mathrm{bc}$ & $12.7 \mathrm{ab}$ & $12.8 \mathrm{ab}$ & $14.1 \mathrm{a}$ & 1.7 & 0.7 \\
\hline & Inoculated & $5.5 \mathrm{cz}$ & $8.5 \mathrm{bz}$ & $11.0 \mathrm{az}$ & $12.2 \mathrm{a}$ & $11.5 \mathrm{az}$ & $12.6 \mathrm{az}$ & 2.1 & \\
\hline \multirow[t]{2}{*}{ Plant growth stage (Haun units) } & Control & $1.6 \mathrm{c}$ & $2.0 \mathrm{~b}$ & $2.0 \mathrm{~b}$ & $2.2 \mathrm{a}$ & $2.3 \mathrm{a}$ & $2.4 \mathrm{a}$ & 0.2 & ns \\
\hline & Inoculated & $1.4 \mathrm{~d}$ & $1.8 \mathrm{c}$ & $2.0 \mathrm{bc}$ & $2.3 \mathrm{a}$ & $2.2 \mathrm{ab}$ & $2.4 \mathrm{a}$ & 0.3 & \\
\hline \multirow[t]{2}{*}{ Grain yield (kg/ha) } & Control & $668 \mathrm{~d}$ & $1,855 \mathrm{c}$ & $3,660 \mathrm{~b}$ & $3,727 \mathrm{~b}$ & $3,689 \mathrm{~b}$ & 5,596 a & 950 & ns \\
\hline & Inoculated & $680 \mathrm{~d}$ & $1,837 \mathrm{c}$ & $3,222 \mathrm{~b}$ & $3,095 \mathrm{~b}$ & $3,305 \mathrm{~b}$ & 6,014 a & 963 & \\
\hline \multicolumn{10}{|l|}{2007 crop year } \\
\hline \multirow[t]{2}{*}{ Stand density (seedlings/m) } & Control & $3.6 \mathrm{~b}$ & $24.4 \mathrm{a}$ & $30.9 \mathrm{a}$ & $29.0 \mathrm{a}$ & $26.0 \mathrm{a}$ & $28.2 \mathrm{a}$ & 14.3 & ns \\
\hline & Inoculated & $9.9 \mathrm{~b}$ & $24.6 \mathrm{a}$ & $31.5 \mathrm{a}$ & $28.7 \mathrm{a}$ & $26.3 \mathrm{a}$ & $30.1 \mathrm{a}$ & 10.7 & \\
\hline \multirow[t]{2}{*}{ Plant height $(\mathrm{cm})$} & Control & $15.8 \mathrm{~d}$ & $27.4 \mathrm{c}$ & $29.8 \mathrm{bc}$ & $32.1 \mathrm{ab}$ & $32.4 \mathrm{ab}$ & $35.8 \mathrm{a}$ & 4.4 & 1.9 \\
\hline & Inoculated & $14.0 \mathrm{c}$ & $21.5 \mathrm{bz}$ & $27.8 \mathrm{az}$ & $31.0 \mathrm{a}$ & $29.1 \mathrm{az}$ & $31.9 \mathrm{az}$ & 5.4 & \\
\hline \multirow[t]{2}{*}{ Plant growth stage (Haun units) } & Control & $1.9 \mathrm{c}$ & $2.3 \mathrm{~b}$ & $2.3 \mathrm{~b}$ & $2.4 \mathrm{ab}$ & $2.5 \mathrm{ab}$ & $2.6 \mathrm{a}$ & 0.2 & ns \\
\hline & Inoculated & $1.7 \mathrm{e}$ & $2.0 \mathrm{~d}$ & $2.2 \mathrm{~cd}$ & $2.5 \mathrm{~b}$ & $2.5 \mathrm{bc}$ & $2.8 \mathrm{a}$ & 0.3 & \\
\hline \multirow[t]{2}{*}{ Grain yield (kg/ha) } & Control & $843 \mathrm{~d}$ & $2,062 \mathrm{c}$ & $2,868 \mathrm{c}$ & $3,863 \mathrm{~b}$ & $4,585 \mathrm{~b}$ & 5,931 a & 862 & ns \\
\hline & Inoculated & $860 \mathrm{~d}$ & $2,071 \mathrm{c}$ & $2,272 \mathrm{c}$ & $3,491 \mathrm{~b}$ & $5,651 \mathrm{a}$ & $6,133 \mathrm{a}$ & 768 & \\
\hline
\end{tabular}

\footnotetext{
${ }^{y}$ Means followed by the same letter (a-d) within each row did not differ significantly at $P=0.05$ according to Fisher's least significant difference test. When a
} significant difference occurred between inoculum treatments, that occurrence is designated by the letter ' $\mathrm{z}$ ' in the row of data for the inoculated treatment. 
this relationship was not significant during either of the individual years (Table 1).

Grain yield and kernel weight. Grain yields were significantly influenced by the effects of year $(P<0.0001)$ and distance $(P<$ $0.0001)$ but not by inoculation $(P=0.6505)$. Interactions were significant for year $\times$ distance $(P<0.0001)$, year $\times$ inoculation $(P=$ $0.0200)$, and year $\times$ distance $\times$ inoculation $(P=0.0001)$. Grain yield was greater during 2007 than 2005 (3,386 versus 3,120; LSD $_{0.05}=$ 72) and was progressively greater as distance increased from the trees (Table 1). When evaluated by individual year, the distance treatment had a significant influence on yield in control as well as inoculated treatments each year (Table 1), but the inoculation treatments did not differ significantly during either year. Grain kernel weight was not significantly influenced by any of the measured treatment effects or their interactions.

Fusarium crown rot. The incidence of subcrown internode lesions was significantly influenced by year $(P<0.0001)$ but not by distance from the tree line or addition of inoculum, or of any possible interactions of these factors (data not shown). Lesions were much more prevalent during the lowest-rainfall year (2005) than during the more normal 2007 (means of $14.6 \%$ versus $1.3 \%$ plants, $\mathrm{LSD}_{0.05}=3.5$ ). However, when evaluated for individual years, the incidence of subcrown internode lesions did not differ significantly between inoculated treatments; means in controls versus inoculated plots were $13.8 \%$ versus $15.4 \%$ during 2005 and $1.1 \%$ versus $1.5 \%$ during 2007. Means also did not differ for distance from the tree line during either year; means ranged from 7.6 to $25.0 \%$ in the control plots over the six distance intervals during 2005 and from 5.0 to $27.5 \%$ in the inoculated plots. Browning of internal crown tissue was not observed at any time during either year.

Whiteheads were counted on five dates during 2005 and three dates during 2007. For the purpose of pooling data to evaluate a potential influence of year, the last three counting dates for 2005 were pooled with the three dates for 2007 . The analyses therefore consisted of a 'first' counting date of 29 June 2005 and 29 June 2007 , a 'second' date of 30 June 2005 and 2 July 2007, and a 'third' date of 1 July 2005 and 5 July 2007. For all three counting dates, there were significant effects of distance $(P<0.0001)$ and inoculation
$(P<0.004)$ but not of year $(P>0.28)$. The inoculation $\times$ distance interaction was highly significant $(P<0.0001)$ for all three counting dates, and the inoculation $\times$ distance $\times$ year interaction was significant only for the first date $(P=0.0096)$. The latter interaction indicated that the mid-distance elevation of whiteheads was greater during 2005 than 2007. The significant main effect for inoculation on each date showed that whitehead density was increased by addition of inoculum. Two-year means for this effect in the control and inoculum treatments, respectively, were 2.5 versus $14.6 / \mathrm{m}^{2}$ $\left(\mathrm{LSD}_{0.05}=4.8\right)$ for the 'first' count, 2.0 versus $19.4 / \mathrm{m}^{2}\left(\mathrm{LSD}_{0.05}=\right.$ $5.9)$ for the 'second' count, and 2.1 versus $23.7 / \mathrm{m}^{2}\left(\mathrm{LSD}_{0.05}=3.0\right)$ for the 'third' count. The significant main effect for distance on each date showed that whitehead density was always significantly higher at distances of $9,15,23$, and $30 \mathrm{~m}$ compared with 5 and $46 \mathrm{~m}$ distances from the tree line.

The influence of inoculation on whitehead expression during individual years and counting dates is shown in Table 2. For each whitehead counting date during each year, there were significant $(P<0.01)$ main effects of distance and inoculum and of the distance $x$ inoculum interaction. The interaction indicated that the significant effect of distance occurred in the inoculated but not control plots. The effect of distance in control plots was never significant when evaluated individually for each counting date during each year. In inoculated soil, the significant main effect for distance during each date showed that lowest density of whiteheads always occurred at points nearest and furthest from the tree line and became elevated at distances between 9 and $30 \mathrm{~m}$ from the tree line. This effect is illustrated by plots of whitehead density in control and inoculated treatments on five counting dates during 2005 and three counting dates during 2007 (Fig. 3). Each year, the density of whitehead expression on the earliest counting dates occurred in the 9- to 15-m distances. On successive counting dates, the peak density of whiteheads rapidly shifted from closer to greater distances from the tree line. Each year, during the last counting date, the maximum density of whiteheads attained a broad peak over the range of 9 to $30 \mathrm{~m}$ from the tree line. Very few whiteheads occurred in the noninoculated treatment and in the remainder of the wheat field. At the 46-m distance, the density of whiteheads

Table 2. Whiteheads and browned basal internodes caused by Fusarium crown rot of winter wheat as influenced by distance from an Austrian pine tree windbreak and presence or absence of supplemental inoculum of Fusarium pseudograminearum during two crop years

\begin{tabular}{|c|c|c|c|c|c|c|c|c|c|}
\hline \multirow[b]{2}{*}{ Date } & \multirow{2}{*}{$\begin{array}{l}\text { Inoculum } \\
\text { treatment }\end{array}$} & \multicolumn{7}{|c|}{ Distance from tree line $(\mathrm{m})$} & \multirow{2}{*}{$\begin{array}{c}\text { Inoculum } \\
\text { LSD }_{0.05}\end{array}$} \\
\hline & & 5 & 9 & 15 & 23 & 30 & 46 & LSD $_{0.05}$ & \\
\hline & & \multicolumn{8}{|c|}{ Whiteheads $/ m^{2}$} \\
\hline \multirow{2}{*}{24 June 2005} & Control & $0.8 \mathrm{a}^{\mathrm{y}}$ & $0.8 \mathrm{a}$ & $2.3 \mathrm{a}$ & $3.8 \mathrm{a}$ & $2.7 \mathrm{a}$ & $2.7 \mathrm{a}$ & ns & 3.6 \\
\hline & Inoculated & $2.9 \mathrm{c}$ & $13.2 \mathrm{abz}$ & $18.2 \mathrm{az}$ & $8.6 \mathrm{bcz}$ & $5.6 \mathrm{bc}$ & $1.7 \mathrm{c}$ & 6.4 & \\
\hline \multirow{2}{*}{27 June 2005} & Control & $1.3 \mathrm{a}$ & $1.8 \mathrm{a}$ & $2.4 \mathrm{a}$ & $1.0 \mathrm{a}$ & $1.9 \mathrm{a}$ & $2.6 \mathrm{a}$ & ns & 2.6 \\
\hline & Inoculated & $7.1 \mathrm{~cd}$ & $19.2 \mathrm{az}$ & $15.7 \mathrm{abz}$ & $9.4 \mathrm{bcz}$ & $4.2 \mathrm{~cd}$ & $1.7 \mathrm{~d}$ & 6.4 & \\
\hline \multirow{2}{*}{29 June 2005} & Control & $1.7 \mathrm{a}$ & $1.5 \mathrm{a}$ & $2.1 \mathrm{a}$ & $1.3 \mathrm{a}$ & $2.7 \mathrm{a}$ & $3.4 \mathrm{a}$ & ns & 2.5 \\
\hline & Inoculated & $10.2 \mathrm{cz}$ & $22.8 \mathrm{az}$ & $25.1 \mathrm{az}$ & $17.8 \mathrm{abz}$ & $12.7 \mathrm{bcz}$ & $2.3 \mathrm{~d}$ & 7.5 & \\
\hline \multirow[t]{2}{*}{30 June 2005} & Control & $1.7 \mathrm{a}$ & $1.7 \mathrm{a}$ & $1.3 \mathrm{a}$ & $0.6 \mathrm{a}$ & $0.8 \mathrm{a}$ & $2.9 \mathrm{a}$ & $\mathrm{ns}$ & 3.5 \\
\hline & Inoculated & $11.7 \mathrm{bz}$ & $23.8 \mathrm{az}$ & $26.8 \mathrm{az}$ & $23.4 \mathrm{az}$ & $25.5 \mathrm{az}$ & $2.3 \mathrm{~b}$ & 10.9 & \\
\hline \multirow[t]{2}{*}{1 July 2005} & Control & $1.5 \mathrm{a}$ & $2.9 \mathrm{a}$ & $2.1 \mathrm{a}$ & $1.3 \mathrm{a}$ & $1.3 \mathrm{a}$ & $2.7 \mathrm{a}$ & ns & 1.2 \\
\hline & Inoculated & $12.3 \mathrm{cz}$ & $25.9 \mathrm{bz}$ & $31.8 \mathrm{az}$ & $32.2 \mathrm{az}$ & $34.7 \mathrm{az}$ & $3.8 \mathrm{~d}$ & 3.7 & \\
\hline \multirow[t]{2}{*}{29 June 2007} & Control & $2.3 \mathrm{a}$ & $2.5 \mathrm{a}$ & $4.8 \mathrm{a}$ & $2.3 \mathrm{a}$ & $2.0 \mathrm{a}$ & $3.8 \mathrm{a}$ & ns & 1.9 \\
\hline & Inoculated & $6.0 \mathrm{bz}$ & $19.5 \mathrm{az}$ & $19.0 \mathrm{az}$ & $15.5 \mathrm{az}$ & $20.5 \mathrm{az}$ & $3.5 \mathrm{~b}$ & 5.8 & \\
\hline \multirow[t]{2}{*}{2 July 2007} & Control & $2.0 \mathrm{a}$ & $2.3 \mathrm{a}$ & $2.5 \mathrm{a}$ & $2.0 \mathrm{a}$ & $1.8 \mathrm{a}$ & $4.5 \mathrm{a}$ & ns & 2.2 \\
\hline & Inoculated & $12.5 \mathrm{cz}$ & $27.3 \mathrm{abz}$ & $31.5 \mathrm{az}$ & $21.8 \mathrm{bz}$ & $23.0 \mathrm{bz}$ & $3.0 \mathrm{~d}$ & 6.9 & \\
\hline \multirow[t]{3}{*}{5 July 2007} & Control & $2.3 \mathrm{a}$ & $3.0 \mathrm{a}$ & $1.8 \mathrm{a}$ & $1.5 \mathrm{a}$ & $2.4 \mathrm{a}$ & $3.0 \mathrm{a}$ & ns & 3.0 \\
\hline & Inoculated & $17.3 \mathrm{bz}$ & $29.0 \mathrm{az}$ & $32.8 \mathrm{az}$ & $29.0 \mathrm{az}$ & $33.8 \mathrm{az}$ & $2.5 \mathrm{c}$ & 10.0 & \\
\hline & & \multicolumn{8}{|c|}{ Browning of basal culms (\% tillers) } \\
\hline \multirow[t]{2}{*}{ August 2005} & Control & $31.5 \mathrm{c}$ & $38.3 \mathrm{bc}$ & $40.5 \mathrm{~b}$ & $41.0 \mathrm{~b}$ & $63.5 \mathrm{a}$ & $43.5 \mathrm{~b}$ & 6.4 & 2.6 \\
\hline & Inoculated & $67.3 \mathrm{cz}$ & $72.8 \mathrm{cz}$ & $75.0 \mathrm{bz}$ & $76.5 \mathrm{bz}$ & $90.0 \mathrm{az}$ & $48.5 \mathrm{dz}$ & 5.6 & \\
\hline \multirow[t]{2}{*}{ August 2007} & Control & $34.0 \mathrm{c}$ & $42.0 \mathrm{bc}$ & $46.0 \mathrm{~b}$ & $48.3 \mathrm{~b}$ & $69.0 \mathrm{a}$ & $49.8 \mathrm{~b}$ & 10.9 & 3.7 \\
\hline & Inoculated & $69.8 \mathrm{dz}$ & $78.3 \mathrm{cz}$ & $81.3 \mathrm{cz}$ & $84.5 \mathrm{bz}$ & $90.5 \mathrm{az}$ & $60.5 \mathrm{ez}$ & 5.2 & \\
\hline
\end{tabular}

${ }^{\mathrm{y}}$ Mean whiteheads $/ \mathrm{m}^{2}$ followed by the same letter (a-e) within each row did not differ significantly at $P=0.05$ according to Fisher's least significant difference test. When a significant difference occurred between inoculum treatments, that occurrence is designated by the letter ' $\mathrm{z}$ ' in the row of data for the inoculated treatment. 
became equal in inoculated and noninoculated plots, suggesting that water stress at that distance was insufficient to incite the expression of whiteheads even in the presence of an elevated population density of the pathogen.

Browning of at least one basal internode of tillers was significantly influenced by year $(P<0.0001)$, distance $(P<0.0001)$, and inoculation $(P=0.0003)$ factors, and by the inoculation $\times$ distance interaction $(P=0.0001)$. The significant interaction revealed that the stem browning became greater with increasing distance from 5 to $30 \mathrm{~m}$ from the tree line and then decreased dramatically at the 46-m interval, and that the range of these differences was greater in the inoculated than in the control treatment. This was clearly apparent for individual years, inoculation, and distance treatments (Table 2). Stem browning was significantly influenced by inoculum and distance treatments each year. Overall, stem browning was greater during 2007 than $2005\left(62.8 \%\right.$ versus $57.4 \%$ LSD $\left._{0.05}=1.3\right)$ and greater in inoculated compared with control plots $(74.6 \%$ versus $45.6 \%$; $\left.\mathrm{LSD}_{0.05}=4.7\right)$. When grouped over years, stem browning was least at the 5-m and 46-m distances from the tree line (each was 50.6\%) and was greatest at the $30-\mathrm{m}$ distance $(78.3 \%)$.

Soil water content. Soil moisture was measured during the 2004 fallow year at four depths in tubes spaced at six distances from the tree line. Measurements were made on six dates from 30 March until 22 June 2004 . Tubes at the 46-m distance were approximately $18 \mathrm{~m}$ outside the zone of visual effect from tree root competition shown in Figure 1. As would be expected, water contents over time varied with
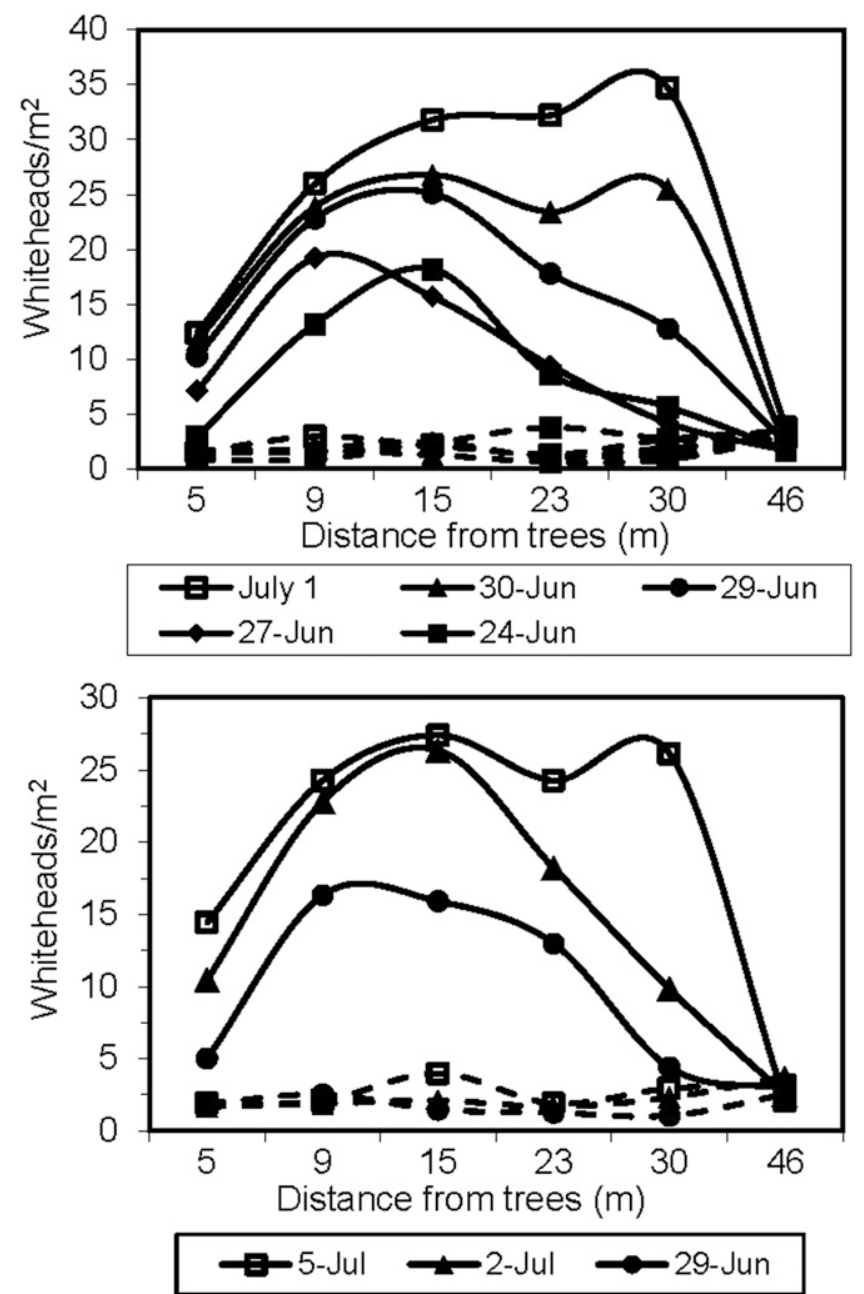

Fig. 3. Whitehead density in winter wheat cv. Tubbs when counted at six distances perpendicular to a row of Austrian pine trees at Pendleton, OR during 2005 (top; five counting dates) and during 2007 (bottom; three counting dates). Plots were either inoculated with a mixture of five isolates of Fusarium pseudograminearum (solid lines) or were not inoculated (dashed lines). rainfall occurrences at $15-\mathrm{cm}$ depth and were more uniform at sampling depths of 46, 76, and $107 \mathrm{~cm}$. For purposes of this paper, we only summarize the mean moisture content for the entire $107-\mathrm{cm}$ soil profile. Mean profile soil moisture content was between 15 and $20 \%$ at all distances from the tree line on 30 March and 9 April, and was lowest $(15 \%)$ in soil closest to the tree line (data not shown). Moisture content increased following rain events during the spring. After 22 April, moisture was always lowest at the 5-m distance from the trees, and was lower at $9,15,23$, and $30 \mathrm{~m}$ distances (21 to $23 \%$ ) than at $46 \mathrm{~m}(25 \%)$, suggesting that tree root competition extended to at least $30 \mathrm{~m}$ from the tree line.

On 4 Oct 2004, when the 2005 wheat crop was being planted following a 14-month fallow period, soil moisture at all depths generally increased with increasing distance from the tree line (Fig. 4, top). At 15-cm depth, moisture contents were similar from 9 to $46 \mathrm{~m}$ from the tree line. At 46-cm depth, moisture content was similar from 23 to $46 \mathrm{~m}$ from the tree line. A similar pattern occurred for the complete soil profile mean moisture content. These data, taken before precipitation began during winter, indicated tree root uptake of water to a distance of at least $46 \mathrm{~m}$ from the tree line, with less uptake beyond $23 \mathrm{~m}$ than at closer distances.

Soil water content was measured at six depths $(10$ to $100 \mathrm{~cm})$ on three dates from early to late spring 2005. This report summarizes the measurements on the last date (12 May), which was about 2 weeks before anthesis in the wheat crop. Rainfall during the two previous months was less than the 20-year mean; 36 and $45 \mathrm{~mm}$ in March
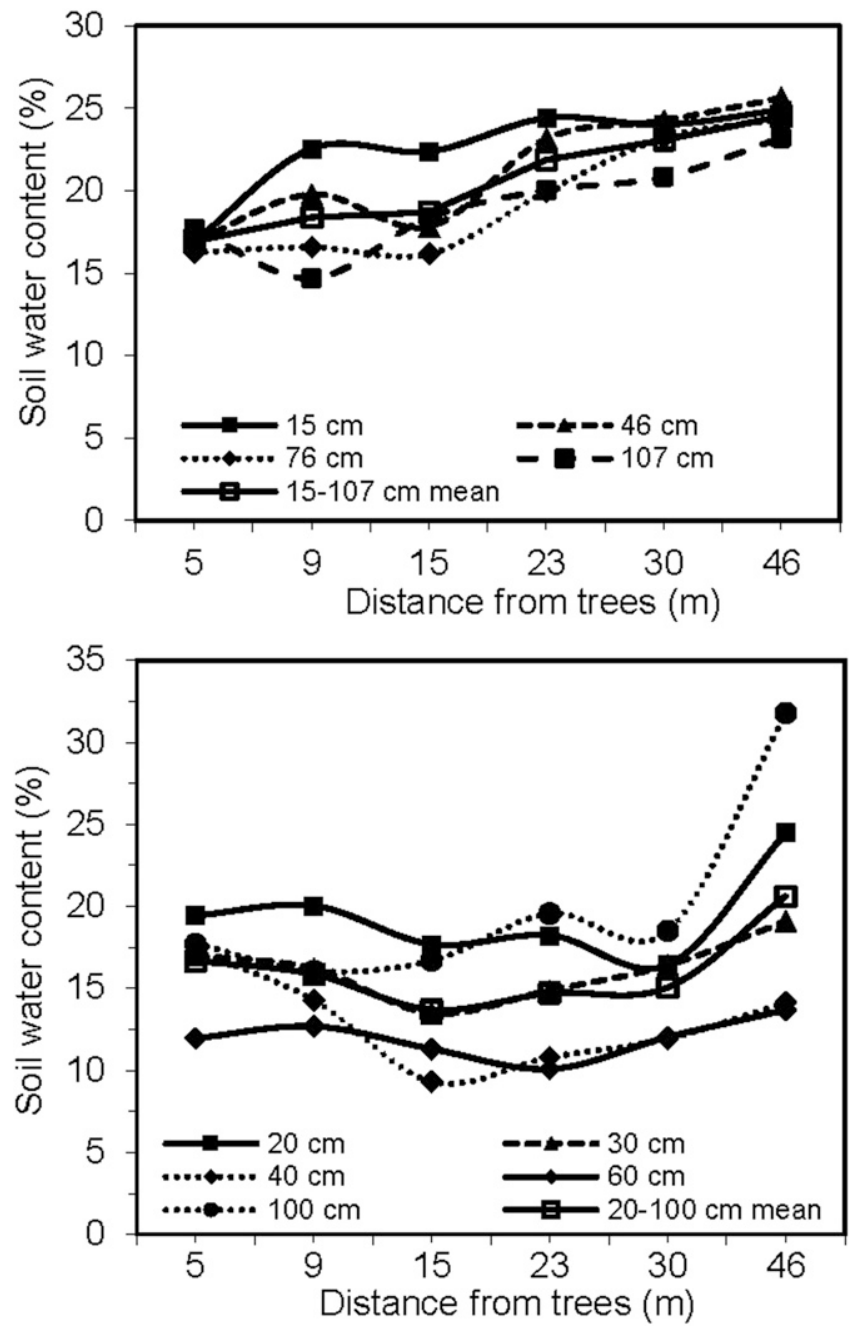

Fig. 4. Soil water content at six distances from an Austrian pine windbreak at Pendleton, OR; top, at four depths under newly planted winter wheat cv. Tubbs on 4 Oct 2004 following a 14-month fallow period and, bottom, at five depths under a winter wheat crop on 12 May 2005. 
and April, respectively. Rains from 3 to 11 May delivered $24 \mathrm{~mm}$ of precipitation over a period that ended 1 day before the soil water content was measured. Soil water content at $20-\mathrm{cm}$ depth declined slightly with increasing distance to $30 \mathrm{~m}$ from the tree line and then increased markedly at $46 \mathrm{~m}$ (Fig. 4, bottom). At 30- and 40-cm depths, the soil water content generally decreased up to $15 \mathrm{~m}$ from the trees but then increased continually at further distances. At 60$\mathrm{cm}$ depth, moisture was relatively uniform with distance, with the lowest amount occurring at $23 \mathrm{~m}$ from the trees. At 100-cm depth, the moisture was far greater at $46 \mathrm{~m}$ than at distances closer to the trees. Mean moisture content over the 20 - to $100-\mathrm{cm}$ profile depth was also greater at $46 \mathrm{~m}$ than at closer distances.

Water was also measured in fallow soil during midspring in 2006 (data not shown). At 100-cm depth, moisture contents were similar from 9 to $46 \mathrm{~m}$ from the tree line. Mean moisture content over the 20 - to $100-\mathrm{cm}$ profile depth declined slightly and continuously from 5 to $30 \mathrm{~m}$ distances, and then rose slightly at $46 \mathrm{~m}$. These data in fallow soil during the springtime confirmed uptake of water by tree roots to a distance of at least $30 \mathrm{~m}$ from the tree line.

During the 2007 wheat crop, the water content patterns during mid-February (data not shown) were similar to those observed during the crop harvested in 2005. Although measurements in 2007 were terminated too early to directly relate to water competition near the time of wheat anthesis, it was noted earlier that rainfall was particularly deficient ( $-27 \%$ of long-term average for the season) during the remainder of the 2007 crop year. Rainfall after mid-February would not have contributed additional moisture at depths greater than $30 \mathrm{~cm}$ of the soil profile.

Associations among plant, water, and disease factors. An important focus of this paper was to examine relationships among plant, crown rot, and soil water factors measured in the inoculated-soil treatment. Because of the high and relatively uniform crown rot symptoms over the 9- to 30-m-distance interval from the tree line in the inoculated treatment, as illustrated in Figure 3, relationships between factors within that interval became of specific interest. Since the percentages of whiteheads declined dramatically between distances of 30 and $46 \mathrm{~m}$, it was also of interest to examine relationships among factors on either side of that transition zone. It is also important to note that soil water was last measured during May in 2005 and during February in 2007, at which times the plants were in the anthesis and seedling growth stages, respectively. Relationships between soil water content with whiteheads and grain yield could not be evaluated during 2007.

Distance interval from 9 to $30 \mathrm{~m}$. Associations among plant, disease, and water factors in the inoculated plots was limited to data grouped over sampling points at 9-, 15-, 23-, and 30-m distances from the tree line. The associations were evaluated by regression

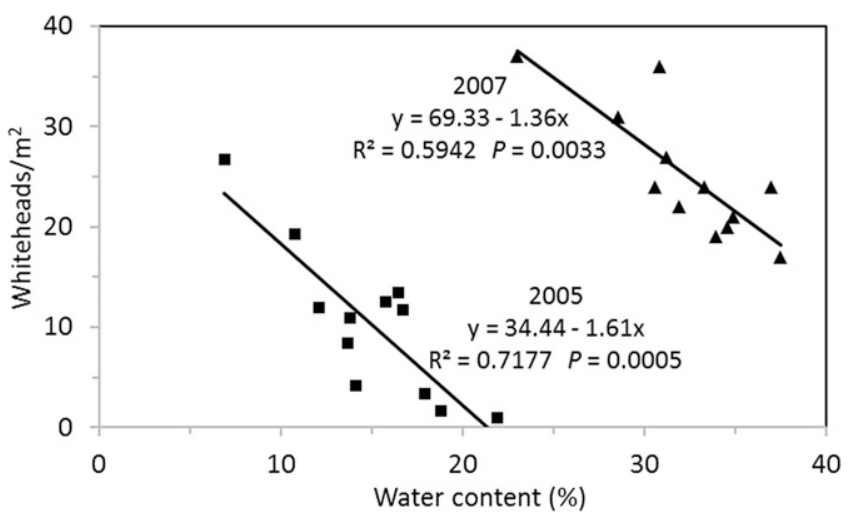

Fig. 5. Associations between soil water content and whitehead density in winter wheat cv. Tubbs inoculated with Fusarium pseudograminearum at three distances (15, 23, and $30 \mathrm{~m}$ ) perpendicular to a row of windbreak trees at Pendleton, OR. Data for 2005 represent whiteheads counted on 27 June and soil water measured at $30-\mathrm{cm}$ depth on 12 May. Data for 2007 represent whiteheads counted on 2 July and soil water measured at $100-\mathrm{cm}$ depth on 15 February. analysis between pairs of factors, with emphasis on relationships between grain yield, kernel weight, soil water, and the various ways in which crown rot was assessed. The incidence of culm browning was never significantly correlated with any measure of plant growth, grain yield, grain kernel weight, or soil water content at individual depths or throughout the 100-cm depth profile.

Grain yield was not correlated with any measure of soil water content during 2005 and could not be evaluated during 2007. Yield was negatively correlated with the percentage of subcrown internodes with visible lesions during $2005(P=0.0156, \mathrm{r}=-0.5926, n=16)$ but not during $2007(P=0.94)$. Yield was significantly negatively associated with whitehead counts during two of five comparisons during 2005, but the correlation coefficients were each very weak, as was clearly illustrated by plotting the data (not shown). The significant correlations occurred for whitehead densities counted on 27 June $2005(P=0.0450, \mathrm{r}=-0.5071, n=16)$ and 29 June $2005(P=0.0419, \mathrm{r}=-0.5136)$. Grain yield tended to be associated with grain kernel weight $(P<0.06, \mathrm{r}>0.48)$. Whitehead densities in 2005 were negatively correlated with kernel weight on 27 June $2005(P=0.0502, r=-0.4950)$ and on 29 June 2005 $(P=0.0386, \mathrm{r}=-0.5208)$.

Whitehead density was never significantly correlated with the incidence of culm browning or lesions on subcrown internodes. Whiteheads on the first counting date during 2005 were significantly correlated only with whiteheads on the second counting date $(P=$ $0.0005)$. Whiteheads on the second date during 2005 were negatively correlated with grain yield $(P=0.0450, \mathrm{r}=-0.5071)$ and grain kernel weight $(P=0.0502, \mathrm{r}=-0.4950)$, and were positively correlated with whiteheads on the first and third $(P=0.0142)$ counting dates but not on the fourth and fifth dates.

As grouped for analysis, the third whitehead counting date included data for both years. Whitehead density on the third date during 2005 was negatively correlated grain yield $(P=0.0419)$ and grain kernel weight $(P=0.0386)$ but not with soil water measurements at any individual depth or of averages across four depth ranges: 10 to $100 \mathrm{~cm}, 20$ to $100 \mathrm{~cm}, 30$ to $100 \mathrm{~cm}$, and 40 to $100 \mathrm{~cm}$. Whitehead density on the fourth counting date during 2005 was negatively correlated with soil water measured at $40-\mathrm{cm}$ depth $(P=0.0216, \mathrm{r}=$ $-0.5685)$ but was not correlated with any other factor. During 2007, whitehead density on the fourth counting date also was not correlated with grain yield or kernel weight. During 2005, whitehead density during the fifth counting date was negatively correlated with soil water content measured at $20-\mathrm{cm}$ depth $(P=0.02, \mathrm{r}=-0.56)$ but with no other factor measured, including soil moisture content averaged over four depth ranges mentioned previously.

Distance interval from 15 to $30 \mathrm{~m}$. When data were grouped over the $15-$ to $30-\mathrm{m}$ interval from the tree line, whiteheads were negatively correlated with at least one measure of soil water for four of the five counting dates during 2005 (24, 27, 29 June and 1 July) and for all three counting dates during 2007. The significant associations during 2007 each related to soil moisture content at the deepest depth measured $(100 \mathrm{~cm})$, presumably in response to the final sampling of soil moisture during late winter (15 February) and meager amount of additional rainfall during the remainder of the growing season. One significant association during each year is illustrated in Figure 5. As with the 9- to 30-m distance interval, there were no significant correlations between grain yield and soil moisture content at any depth or depth range during either year at the 9- to 30-m distance interval.

Transition from distance intervals 30 and $46 \mathrm{~m}$. The focus of this section is on associations among plant, disease, and water factors in inoculated plots on either side of the crown rot-transition zone from 30 to $46 \mathrm{~m}$ from the tree line. During 2005, grain yield was negatively correlated to whitehead density $(P<0.02, \mathrm{r}>-0.79)$ on all counting dates, and was positively associated with soil water measured at 100 cm depth $(P=0.0335, \mathrm{r}=0.7461)$ and as averaged over the 10 - to $100-\mathrm{cm}(P=0.0142, \mathrm{r}=0.8129)$ and $20-$ to $100-\mathrm{cm}(P=0.0500$, $\mathrm{r}=0.7067)$ depth profiles. There were no significant correlations between grain yield and other factors during 2007, or between grain kernel weight and other factors during both years. 
Culm browning was positively correlated with whitehead counts on all dates each year $(P<0.01, \mathrm{r}>0.87)$. During 2005 , culm browning was also negatively correlated with soil water content at 20 - and 100 -cm depths $(P<0.01, \mathrm{r}>-0.85)$, and for each of the four ranges of soil profile depths examined. The correlations were of greater significance for the 10 - to $100-\mathrm{cm}$ and 20 - to 100 -cm depth ranges $(P<$ $0.002, \mathrm{r}>-0.90$ ) than for the $30-$ to $100-\mathrm{cm}$ and $40-$ to $100-\mathrm{cm}$ ranges $(P<0.03, \mathrm{r}>-0.76)$. Culm browning was also significantly correlated with whitehead density for all counting dates each year $(P<$ $0.005, \mathrm{r}>-0.86$ )

Whitehead density on all counting dates during 2005 was negatively correlated with soil water content at $100-\mathrm{cm}$ depth $(P<0.03$, $r>-0.76)$ and for most combinations of whitehead counting dates and depth ranges evaluated for soil moisture. Contrary to results in the 15 to $30 \mathrm{~m}$ distance zone, no significant relationships between whitehead density and soil moisture content were detected in the 30 to $46 \mathrm{~m}$ transition zone during 2007.

\section{Discussion}

An Austrian pine windbreak competed for water and possibly other resources in a zone extending at least $30 \mathrm{~m}(1.8 \mathrm{H} ; 1.8 \times$ height of trees) into an adjacent crop of winter wheat. Severity of Fusarium crown rot during 2 years of study was far less outside the zone of competition than in a zone from 9 to $30 \mathrm{~m}$ from the tree line. This finding demonstrated that it is possible to conduct crown rot research across stress-gradients where windbreaks are common on farms in rainfed semiarid regions, without the necessity to establish an irrigation or rain-exclusion facility. In particular, experiments such as cultivar screening trials could be conducted in nearby blocks that are influenced by two different levels of water stress. The stressed block could be up to $20 \mathrm{~m}$ wide along the length of the windbreak. Alternatively, comparisons of interactions between factors such as nutrition and water, inoculum density and water, light and water, or cultivar tolerance and water could be placed into smaller blocks near the outer limit of the resource competition zone. Such comparisons of interactions would be particularly well suited for precise monitoring of pathogen infection and disease progression through the use of quantitative PCR, to expand upon and to complement similar studies reported by Hogg et al. (2007), Knight and Sutherland (2013, 2015, 2016, 2017), and Knight et al. (2012, 2017).

Very few whiteheads developed in response to crown rot caused by native inoculum at the experimental site. However, when inoculum levels were enhanced with additional Fusarium pseudograminearum, development of whiteheads became prevalent and the density was relatively uniform over distances from 9 to $30 \mathrm{~m}$ $(0.5 \mathrm{H}$ to $1.8 \mathrm{H})$ from the tree line. Whiteheads appeared in the area of tree-wheat competition even during a wetter-than-average year when adequate late-season rainfall nearly eliminated the development of whiteheads in infected crops outside the zone of tree root competition. Whitehead expression was much lower at a distance less than $9 \mathrm{~m}$ from the trees, presumably in response to a lower plant stand density, which would have provided more resources for each plant, or possibly also to shading, which may have reduced the intensity of midsummer heat stress during early mornings. Soil water extraction by the Austrian pines was detected to a distance of at least $30 \mathrm{~m}(1.8 \mathrm{H})$ from the tree line, whereupon the water content at $100-\mathrm{cm}$ depth increased markedly at $46 \mathrm{~m}(2.7 \mathrm{H})$, which was the greatest distance measured. Whitehead expression at $46 \mathrm{~m}$ from the tree line was low and nearly identical in inoculated and noninoculated soil, indicating the absence of sufficient water stress to induce the whitehead symptom. Our results therefore showed that crown rot experiments could be conducted in a 20-m-wide zone (from $0.5 \mathrm{H}$ to $1.8 \mathrm{H}$ ) on the windward (west) side of a mature shelterbelt of Austrian pines at this location.

The zone of resource competition we measured extended to $1.8 \mathrm{H}$. In other semiarid and arid regions, this competitioninduced stress has extended into crops for distances of $1.5 \mathrm{H}$ to 3H (Kort 1988; Sudmeyer and Scott 2002; Sudmeyer et al. 2002a, 2002b). The actual distance will vary depending on tree species and prevailing soil and climatic factors. This procedure could be applied to other regions where crown rot and windbreaks are each common.

We concluded that the Austrian pine windbreak increased disease incidence in inoculated soil and reduced yield of winter wheat mostly by competition for soil water. This corresponds well with previous conclusions regarding drought-induced exacerbation of crown rot. The bigger and more extensive perennial root system of pine trees provided them an enormous competitive advantage over wheat roots. Sudmeyer et al. (2002b) also attributed the reduction in crop yields near pine (Pinus pinaster) and eucalyptus (Eucalyptus globulus) windbreaks to water stress. However, our research revealed very few statistically significant correlations to support a clear relationship between plant stress and disease development, possibly because rainfall events periodically rewetted the upper soil profile. Nevertheless, we found that expression of whiteheads was negatively associated with the soil water content deep within the soil profile, as determined by neutron attenuation. Although this study provided a 'proof-ofhypothesis' for enhanced water stress in wheat plants near a tree windbreak, more comprehensive studies will be required to refine and model the competitive effect of water and other resources over multiple seasons.

The significance of correlations between grain yield and whiteheads was variable over years and depended on the date on which the whiteheads were counted. Whiteheads were significantly negatively correlated with grain yield in only two of eight possible comparisons. Even with a highly significant correlation, the regression coefficients for this relationship were low, indicating the need for caution when interpreting the results. Smiley (2019) also reported that associations between whiteheads and grain yield were variable and unreliable. Smiley et al. (2005a) previously reported field trials in which yields were suppressed $12 \%$ by application of inoculum identical to that applied in the experiments reported here. They noted that the precipitation during those trials was higher than normal, and that the reductions in yield occurred "without notable increases in occurrences of whiteheads" above those caused by the native population. In this study, the thinning of plant stands near the tree line enabled infected surviving plants to mature without expression of whiteheads. Likewise, grain yield was seldom correlated with any of the soil water or disease factors measured in this study. It is unclear why these relationships were not more clearly associated. The use of time domain reflectometry to model depth and time course of water extraction by pine roots may be helpful in future investigations of this competition (Musters and Bouten 1999).

Whiteheads were not significantly correlated with grain kernel weight, as was also reported by Smiley (2019). The converse was predicted since kernel weight is dramatically reduced in tillers that culminate with the formation of a whitehead (Smiley and Patterson 1996; Smiley et al. 2005b). This apparent anomaly probably occurred because the combine's fan would have separated many or most of the shriveled, light-weight kernels from the denser, plumper kernels and expelled them with the chaff. As such, many or most shriveled kernels from whiteheads were probably removed from the grain that was used to measure yield and kernel weight.

Whiteheads were also seldom significantly correlated with incidence and severity of lesions on subcrown internodes, rotting of crown tissue, browning of the sheath of the first-formed leaf (data not presented), or browning of one or more tiller internode. Reports of crown rot incidence or severity are commonly based upon only one of those symptom characteristics. This research and that reported by Smiley (2019) showed that these visible symptoms are not closely related, probably because of the stronger influence of water stress and perhaps other edaphic factors on the formation of whiteheads at the end of the season, and a lesser influence of these factors on initial infection and development of symptoms on subcrown internodes of seedlings. Environmental effects on potential associations between symptoms of Fusarium crown rot were previously discussed by Burgess et al. (2001). In the present experiment, it was of particular interest that counts of whitehead density on a particular date were not correlated with counts made 1 or 2 days earlier or later. This presumably indicated a dynamic pattern of whitehead expression that 
advances rapidly through the wheat canopy during the short time interval that whiteheads are expressed. Smiley (2019) also reported that the date on which the peak percentage of whiteheads occurred differed among individual wheat cultivars. More research is required to define the precise factors that influence the timing of whitehead expression within individual cultivars as well as between cultivars. The application of DNA-based pathogen quantification methods could be used to eliminate this potential source of visual error (Hogg et al. 2007; Hollaway et al. 2013; Knight and Sutherland 2015; Knight et al. 2017).

Browning of internal crown tissue was not observed at any time during either year. This was presumed to have occurred because we dissected crowns during February, which may have been too early to detect this symptom of crown rot during the years of our study. However, at locations receiving less annual precipitation than at our experimental site, during particularly dry years, we have observed rotted, brown crowns as early as November on winter wheat planted during September (R. Smiley, unpublished observation).

It was especially interesting and puzzling that the incidence of basal stem browning was much higher than would have been predicted from observations of other symptoms of crown rot. Internode browning was present on more than $45 \%$ of tillers in noninoculated plots and in about $75 \%$ of tillers in inoculated plots. The browning was prevalent even at the 46-m distance from the tree line, where whitehead density was no longer enhanced by inoculation of soil with additional $F$. pseudograminearum. Contrary to expectations, browning of stems was more prevalent during the wetter year than during the drier year. These results contrast with the much lower incidence of lesions on subcrown internodes $(15 \%$ versus $1 \%$ during the drier and wetter year, respectively), without a significant influence of inoculum application. Likewise, the browning of basal stems was unrelated to the expression of whiteheads, which were very sparse in noninoculated plots and prevalent in inoculated plots in the zone between 9 and $30 \mathrm{~m}$ from the tree line, but sparse at the 46-m distance. It will be important to determine whether similar discrepancies in symptom occurrence are also present in more uniform field trials in which disease ratings typically rely on the use of only one of these symptoms, usually either whiteheads or stem browning. Alternatively, it will be important to determine whether the unconventional use of tree root competition led to anomalies in the ratings of stem browning. For instance, potential nutritional and water gradients across our study area could have created differences in straw color that masked our ability to visually rate differences in stem browning caused by Fusarium crown rot. In fertilizer trials it is common for wheat tillers in plots with higher fertility to be darker than tillers in plots with lower fertility. The application of DNA-based pathogen quantification methods could be used to eliminate this potential source of visual error (Hogg et al. 2007; Hollaway et al. 2013; Knight and Sutherland 2015; Knight et al. 2017).

Other factors including shading, nutrition, and allelopathy may also affect crops growing adjacent to windbreak trees. The trees at Pendleton shaded part of the experimental area during the morning, but the crop was in full sunlight from midmorning to late afternoon. In view of the conclusion of Sudmeyer et al. (2002b) that competition for nutrients and light appeared to have little effect on wheat yield near windbreaks in Western Australia, we also assumed that shading had minimal effect on our observations at distances greater than $9 \mathrm{~m}(0.5 \mathrm{H})$ from the row of Austrian pines.

Allelopathy is another possible stress factor that was not studied in our experiment. Allelopathy is the production of biochemicals that benefit or adversely affect other plants. The lack of understory growth within $5 \mathrm{~m}(0.3)$ of the Austrian pine tree trunks could be an indication of adverse allelopathic effects or of severe competition for water, light, or nutrients. For example, red pine ( $P$. densiflora) and black pine ( $P$. thumbergii) impart strongly adverse allelopathic effects on nearby plants (Rizvi et al. 1992). Allelopathic effects of Aleppo pine ( $P$. halepensis) was affected by the tree age; inhibition of target species growth by young trees was affected mostly by leachates from needles, whereas inhibition by trees older than 30 years was caused mostly by root exudates (Fernandez et al. 2006). In our study, wheat stand density, plant height, and plant growth stage did not differ significantly across the presumed extent of tree root competition. Nevertheless, potential allelopathic interactions and shading effects on wheat growth and Fusarium crown rot near the tree line, greater uniformity of the disease at distances from 9 to $30 \mathrm{~m}$ from the trees, and increase in wheat yield across the interval from 30 to $46 \mathrm{~m}$ collectively indicate that Fusarium crown rot experiments should be conducted in the zone from 9 to $30 \mathrm{~m}(0.5 \mathrm{H}$ to $1.8 \mathrm{H})$ from the row of Austrian pines at this location.

This research described a new method for studying Fusarium crown rot in semiarid regions where wheat is produced near a windbreak. The concept for our use of tree root competition was opposite of that used for line-source irrigation studies. This experimental approach may also be of value for investigations of drought tolerance and other stress-related diseases of crops. Likewise, we determined that crop experiments should be separated from the tree line by a distance of at least three times the height of the trees if the intent is to eliminate tree root competition as a source of variability in agricultural experiments. However, the ultimate utility of the tree competition concept will require a better understanding of contributions of water, soil fertility, shading, and allelopathy to the variability we observed in the zone of resource completion between tree roots and crop roots.

This research also revealed important questions regarding the interpretation of whitehead counts that are frequently released to farmers, extensionists, agronomists, and other agricultural practitioners as a measure of Fusarium crown rot incidence or severity. Our research confirmed previous reports that this disease symptom is an unreliable indicator of disease severity and is often not correlated with other crown rot symptoms or with grain yield or grain test weight.

\section{Acknowledgments}

The authors appreciated technical assistance by Sandra Easley, Jennifer Gourlie, Chris Humphreys, Larry Pritchett, Karl Rhinhart, Jason Sheedy, Alison Thompson, Paul Thorgersen, Ruth Whittaker, and seasonal employees.

\section{Literature Cited}

Alemu, M. M. 2016. Ecological benefits of trees as windbreaks and shelterbelts Int. J. Ecosyst. 6:10-13.

Bates, C. B. 1911. Windbreaks: Their Influence and Value.USDA Forest Service Bull. 86. Government Printing Service, Washington, D.C.

Bennell, M. R., and Verbyla, A. P. 2008. Quantifying the response of crops to shelter in the agricultural regions of South Australia. Aust. J. Agric. Res. 59: 950-957.

Bird, P. R., Bicknell, D., Bulman, P. A., Burke, S. J. A., Leys, J. F., Parker, J. N., Van der Sommen, F. J., and Voller, P. 1992. The role of shelter in Australia for protecting soils, plants and livestock. Agrofor. Syst. 20:59-86.

Brenner, A. J. 1991. Tree-Crop Interactions within a Sahelian Windbreak System. $\mathrm{Ph}$.D. diss. University of Edinburgh, Scotland.

Burgess, L. W., Backhouse, D., Summerell, B. A., and Swan, L. J. 2001. Crown rot of wheat. Pages 271-294 in: Fusarium. B. A. Summerell, J. F. Leslie, D. Backhouse, W. L. Bryden, and L. W. Burgess, eds. American Phytopathological Society, St. Paul, MN

Chen, C., Payne, W. A., Smiley, R. W., and Stoltz, M. A. 2003. Yield and wateruse efficiency of eight wheat cultivars planted on seven dates in northeastern Oregon. Agron. J. 95:836-843.

Cook, R. J. 1968. Fusarium root and foot rot of cereals in the Pacific Northwest Phytopathology 58:127-131.

Cook, R. J. 1980. Fusarium foot rot of wheat and its control in the Pacific Northwest. Plant Dis. 64:1061-1066.

Cook, R. J. 1981. Fusarium diseases of wheat and other small grains in North America. Pages 39-52 in: Fusarium: Diseases, Biology and Taxonomy. P. E. Nelson, T. A. Toussoun, and R. J. Cook, eds. The Pennsylvania State Univ. Press, University Park, PA.

Cook, R. J. 1990. Diseases caused by root-infecting pathogens in dryland agriculture. Adv. Soil Sci. 13:215-239.

Cook, R. J., and Papendick, R. I. 1970. Soil water potential as a factor in the ecology of Fusarium roseum f. sp. cerealis 'Culmorum'. Plant Soil 32:131-145.

Davies, P. 2014. Crown rot pre-breeding programs. GroundCover Supp. Issue 111 (June 30, 2014). Grains Res. and Devel. Corp., Canberra, Australia.

Fernandez, C., Lelong, B., Vila, B., Mevy, J.-P., Robles, C., Greff, S., Dupouyet, S., and Bousquet-Mélou, A. 2006. Potential allelopathic effect of Pinus halepensis in the secondary succession: An experimental approach. Chemoecology 16:97-105.

Finney, K. F., Yamazaki, W. T., Youngs, V. L., and Rubenthaler, G. L. 1987 Quality of hard, soft, and durum wheats. Pages 677-748 in: Wheat and 
Wheat Improvement, 2nd ed. E. G. Heyne, ed. Agron. No. 13, Amer. Soc. Agron., Madison, WI.

Greb, B. W., and Black, A. L. 1961. Effects of windbreak plantings on adjacent crops. J. Soil Water Conserv. 16:223-227.

Haun, J. R. 1973. Visual quantification of wheat development. Agron. J. 65: 116-119.

Hogg, A. C., Johnson, R. H., and Dyer, A. T. 2007. Applying real-time quantitative PCR to Fusarium crown rot of wheat. Plant Dis. 91:1021-1028.

Hollaway, G. J., Evans, M. L., Wallwork, H., Dyson, C. B., and McKay, A. C. 2013. Yield loss in cereals, caused by Fusarium culmorum and F. pseudograminearum, is related to fungal DNA in soil prior to planting, rainfall, and cereal type. Plant Dis. 97:977-982.

Hollaway, G. J., and Exell, G. K. 2010. Survey of wheat crops for white heads caused by crown rot in Victoria, 1997-2009. Australas. Plant Pathol. 39: 363-367.

Klein, T. A., Burgess, L. W., and Ellison, F. W. 1991. The incidence and spatial patterns of wheat plants infested by Fusarium graminearum Group 1 and the effect of crown rot on yield. Aust. J. Agric. Res. 42:399-407.

Knight, N. L., Macdonald, B., and Sutherland, M. W. 2017. Colonization of durum wheat (Triticum turgidum L. var. durum) culms exhibiting premature senescence (dead heads) associated with Fusarium pseudograminearum crown rot. Plant Dis. 101:1788-1794.

Knight, N. L., Martin, A., Sutherland, M. W., and Herde, D. J. 2012. Assessment of infection by Fusarium pseudograminearum in wheat seedling tissues using quantitative PCR and a visual discoloration scale. Plant Dis. 96:1661-1669.

Knight, N. L., and Sutherland, M. W. 2013. Spread of Fusarium pseudograminearum in wheat seedling tissues from a single inoculation point. Australas. Plant Pathol. 42:609-615.

Knight, N. L., and Sutherland, M. W. 2015. Culm discolouration as an indicator of Fusarium pseudograminearum biomass. Australas. Plant Pathol. 44: 319-326.

Knight, N. L., and Sutherland, M. W. 2016. Histopathological assessment of Fusarium pseudograminearum colonization of cereal culms during crown rot infections. Plant Dis. 100:252-259.

Knight, N. L., and Sutherland, M. W. 2017. Assessment of Fusarium pseudograminearum and $F$. culmorum biomass in seedlings of potential host cereal species. Plant Dis. 101:2116-2122.

Kort, J. 1988. Benefits of windbreaks to field and forage crops. Agr. Ecosyst. Environ. 22/23:165-190.

Liddell, C. M., Burgess, L. W., and Taylor, P. W. J. 1986. Reproduction of crown rot of wheat by Fusarium graminearum Group 1 in the greenhouse. Plant Dis. 70: $632-635$

Liu, X., and Liu, C. 2016. Effects of drought-stress on Fusarium crown rot development in barley. PLoS One 11:e0167304

Lyles, L., Tatarko, J., and Dickerson, J. D. 1984. Windbreak effects on soil water and wheat yields. Trans. Am. Soc. Agric. Eng. 22:69-72.

Musters, P. A. D., and Bouten, W. 1999. Assessing rooting depths of an Austrian pine stand by inverse modeling soil water content maps. Water Resour. Res. 35: 3041-3048.

Nelson, P. E., Toussoun, T. A., and Marasas, W. F. O. 1983. Fusarium Species: An Illustrated Manual for Identification. The Pennsylvania State Univ. Press, University Park.

NRCS. 2009. Windbreak/Shelterbelt Establishment: Conservation Practice Standard for Minnesota (Code 380).U.S. Dep. Agric. Nat. Res. Cons. Serv., St. Paul, MN

Nuberg, I. K. 1998. Effect of shelter on temperate crops: A review to define research for Australian conditions. Agrofor. Syst. 41:3-34

Papendick, R. I., and Cook, R. J. 1974. Plant water stress and development of Fusarium foot rot in wheat subjected to different cultural practices. Phytopathology 64:358-363.

Poole, G. J., Smiley, R. W., Walker, C., Huggins, D., Rupp, R., Abatzoglou, J., Garland-Campbell, K., and Paulitz, T. C. 2013. Effect of climate on the distribution of Fusarium spp. causing crown rot of wheat in the Pacific Northwest of the United States. Phytopathology 103:1130-1140.

Rasmussen, S. D., and Shapiro, C. A. 1990. Effect of tree root-pruning adjacent to windbreaks on corn and soybeans. J. Soil Water Conserv. 45:571-575.

Read, R. A. 1964. Tree windbreaks for the central Great Plains. U.S. Dep. Agric Forest Service, Agric. Handb. No. 250.

Rizvi, S. J. H., Haque, H., Singh, V. K., and Rizvi, V. 1992. A discipline called allelopathy. Pages 1-10 in: Allelopathy. S. J. H. Rizvi and V. Rizvi, eds. Chapman and Hall, London.

Ross, C. R. 1972. Eastern Oregon Windbreak Trees and Shrubs. Ext. Serv. Spec. Rep. 371. Oregon State Univ., Corvallis.

Schilling, A. G., Möller, E. M., and Geiger, H. H. 1996. Polymerase chain reactionbased assays for species-specific detection of Fusarium culmorum, F. graminearum, and $F$. avenaceum. Phytopathology 86:515-522.

Schillinger, W. R., Papendick, R. I., Guy, S. O., Rasmussen, P. E., and van Kessel, C. 2006. Dryland cropping systems in the western United States. Pages 365-393 in: Dryland Agriculture, 2nd ed. G. A. Peterson, P. W. Unger, and W. A. Payne, eds. Agron. Monogr. 23. American Society of Agronomy, Madison, WI.

Smiley, R. W. 2009. Water and temperature parameters associated with winter wheat diseases caused by soilborne pathogens. Plant Dis. 93:73-80.

Smiley, R. W. 2019. Fusarium crown rot whitehead symptom as influenced by wheat crop management and sampling date. Plant Dis. In press.

Smiley, R. W., Backhouse, D., Lucas, P., and Paulitz, T. C. 2009. Diseases which challenge global wheat production - root, crown, and culm rots. Pages 125-153 in: Wheat: Science and Trade. B. F. Carver, ed. WileyBlackwell, Ames, IA.

Smiley, R. W., Collins, H. P., and Rasmussen, P. E. 1996. Diseases of wheat in long-term agronomic experiments at Pendleton, Oregon. Plant Dis. 80: 813-820.

Smiley, R. W., Gourlie, J. A., Easley, S. A., and Patterson, L.-M. 2005a Pathogenicity of fungi associated with the wheat crown rot complex in Oregon and Washington. Plant Dis. 89:949-957.

Smiley, R. W., Gourlie, J. A., Easley, S. A., Patterson, L.-M., and Whittaker, R. G. 2005 b. Crop damage estimates for crown rot of wheat and barley in the Pacific Northwest. Plant Dis. 89:595-604.

Smiley, R. W., and Patterson, L.-M. 1996. Pathogenic fungi associated with Fusarium foot rot of winter wheat in the semiarid Pacific Northwest. Plant Dis. 80:944-949.

Sprackling, J. J., and Read, R. 1979. Tree root systems in eastern Nebraska. Cons. Bull. No. 37. Univ. of Nebraska, Lincoln.

Sudmeyer, R. A., Adams, M., Eastham, J., Scott, P. R., Hawkins, W., and Rowland, I. 2002a. Broadacre crop yield in the lee of windbreaks in the medium and low rainfall areas of south-western Australia. Aust. J. Exp. Agric. 42:739-750.

Sudmeyer, R. A., Hall, D. J. M., Eastham, J., and Adams, M. A. 2002b. The treecrop interface: The effects of root pruning in south-western Australia. Aust. J. Exp. Agric. 42:763-772.

Sudmeyer, R. A., and Scott, P. R. 2002. Characterization of a windbreak system on the south coast of Western Australia. 2. Crop growth. Aust. J. Exp. Agric. 42: 717-727.

Wildermuth, G. B., and McNamara, R. B. 1994. Testing wheat seedlings for resistance to crown rot caused by Fusarium graminearum Group 1. Plant Dis. 78:949-953

Williams, K. J., Dennis, J. I., Smyl, C., and Wallwork, H. 2002. The application of species-specific assays based on the polymerase chain reaction to analyse Fusarium crown rot of durum wheat. Australas. Plant Pathol. 31:119-127.

Yamazaki, W. T., and Greenwood, C. T., eds. 1981. Soft Wheat: Production, Breeding, Milling, and Uses. Amer. Assoc. Cereal Chemists, St. Paul, MN

Yeager, A. F. 1935. Root systems of certain trees and shrubs grown on prairie soils J. Agric. Res. 51:1085-1092.

Zadoks, J. C., Chang, T. T., and Konzak, C. F. 1974. A decimal code for the growth stages of cereals. Weed Res. 14:415-421. 